\title{
Efficacy And Characterization Of Synthesized Zinc Oxide Nanoparticles Against Tribolium Castaneum And Trogoderma Granarium
}

\author{
Faheem Abbas $^{1} \uparrow *$,Shahzad ${ }^{2} \dagger$, Muhammad Farman $^{3}$, Muhammad Mumtaz $^{1}$, Farhan Ashrarf $^{1}$, Muhammad Ishaq $^{1}$, \\ Zeeshan Haider ${ }^{1}$, Ali Raza Ayub ${ }^{1}$, Muhammad Usman Tahir ${ }^{1}$, Syed Aleem Sajid ${ }^{4 *}$ and Maria Khalid ${ }^{1}$ \\ ${ }^{1}$ Department of chemistry, University of Agriculture Faisalabad 38040, Pakistan \\ ${ }^{2}$ Department of chemistry, Government College University Faisalabad, Pakistan \\ ${ }^{3}$ Department of Chemistry, University of Engineering and Technology, Lahore, Pakistan \\ ${ }^{4}$ Department of chemistry, University of Lahore, Pakistan \\ $\dagger$ These authors contributed equally to this work \\ *Corresponding author: shahazadkhan472104@gmail.com
}

DOI: 10.29322/IJSRP.10.03.2020.p9912

http://dx.doi.org/10.29322/IJSRP.10.03.2020.p9912

\begin{abstract}
Nano sciences and nanotechnology are the study of extremely small things at nm scale. The present studies were carried at Chemistry Laboratory, Punjab Bioenergy Institute, University of Agriculture Faisalabad. Different and mixed age Tribolium castaneum and Trogoderma granarium was collected from grain market which is located to be Faisalabad. The population for each of the two insect were acclimatized to the laboratory. To raise homogenous population, pupa of the same age were collected during in rearing of insect and in separate plastic jars for adult emergence ( 2 weeks). After extraction of plant materials, biosynthesis of nanoparticles was done accordingly to standard procedure. Toxicity Bioassays were done by three concentrations $(5,10$ and $15 \%)$ of the plant extracts (for each of the simple plant oils as well as nano-particles). Data according to mortality was recorded after 24,48 and 72 hours of the treatment.Highest mortality $(15.10 \%)$ and lowest $(46.12 \%)$ was noticed against Tribolium castaeium. In case of nanoparticles data, $66.32 \%$ mortality was recorded by $\mathrm{ZnO}$ oxide particles against the Tribolium castanium and $49.51 \%$ against Trogoderma granarium. Repellency bioassay was done by area preference method. $\mathrm{ZnO}$ gave highest repellency 79.17. 77.56\% $\mathrm{ZnO}$ highest replency was, against the Trogoderma granarium.Data of all the bioassays were analyzed by factorial under CRD statistical design.
\end{abstract}

Key words: nanotechnology, Bioenergy, mortality, Tribolium castaeium, $\mathrm{ZnO}$ oxide particles, Trogoderma granarium

\section{INTRODUCTION}

Nano sciences is an emerging and vastly developed form that can encompasses the fundamental's elements which can understand and advanced arising form of exploitation of materials, which have one dimension. It has an ability to control individual atoms and molecules. It is the one of the most effective technology in recent decades [1]. It has an application to control the matter at molecular stage. It also have an ability to design, characterized structural application and also control the shape and size of the molecule at nano scale. Nano particle (Nano powder, Nano cluster, Nano crystal) are the small building block of Nano technology[2]. Recently nanoparticles have become commercial in nature because of their new application such as environmental protection,data storage, biology, cosmetics products, medicines due to their optical, physical and megnatic properties [3].Nano particles can be characterized into following parts such as Quatum dots, organic nanoparticles or metal oxides (Al2O3, In2O3, NiO, Tio2, $\mathrm{ZnO}, \mathrm{ZrO} 2, \mathrm{SnO} 2, \mathrm{CuO}$, $\mathrm{MgO}, \mathrm{Cu} 2 \mathrm{O}, \mathrm{La} 2 \mathrm{O} 3, \mathrm{CeO} 2)$, carbon nanotubes and fullerenes are also part of this and inorganic or metals (Al, $\mathrm{Co}, \mathrm{Ni}, \mathrm{Fe}, \mathrm{Au}, \mathrm{Mo}$, $\mathrm{Zn}, \mathrm{Ag}, \mathrm{Ti}, \mathrm{Bi}, \mathrm{W}$ ) [4]). Store grains and their products are attacked different insects which can cause huge losses. [5]. Storage of cereals is about to $9 \%$ losses occurred in developed countries and 20\% in more developing countries [6]it effects on the qualitative 
and quantitative loses of grains [7].Postharvest loses range from 10 to $25 \%$ throughout the world due to infestation of insect pests and microbial deterioration [8]. Wheat is the staple food of Pakistan, also cultivated all over the world expect the Antarctica [9]. Globally, Pakistan is the $3^{\text {rd }}$ largest food crop and eight in world-wide wheat producing country [10]. All stored grain insect pests most disreputable is red flour beetle Tribolium castaneum (Herbst) (Coleoptera: Tenebrionidae), is a pervasive pest of store commodities like wheat flour and a crushed cereals, is also the cosmopolitan and most distructive insect pest [11]The quality of grains reduced due to frass and excreta in damage grains, it can create an adverse effect on environment but infested grain an acute effect on human health [12]. T. granarium makes unable to germinate the grain because when it attacks there larvae during feeding consume specific nutrients [13].

The T. castaneum and R. dominica are primarily controlled by fumigant insecticides [14]but use of fumigants has become limited due to development of resistance and environmental hazards because of their reckless and injudicious use against these insect pests[15]. Other chemicals like pyrethroids are being also used for the control of stored grains insect-pests, but consistent use of theses insecticides may lead to serious problems related to biochemical and hematological changes in the human beings [16]. Conventional insecticides also pose hazardous effect on non-target organisms including beneficial insects [17]. Due to less efficiency of traditional method can't control the insect pests to damage the store grained crop therefore now we can use the advance technology such as nano materials. Nano materials can deliver the DNA and the many reactive chemicals into plant tissues for the protection of host plants against insect pest.But now we can use the advance technology such as silver, zinc and titanium oxide nanoparticle. It can be prepared through following method such as Physical Method, Chemical Method and Biological Method.

\section{METHODLOGY}

The present works will be carried out at energy physics Laboratory, Punjab Bioenergy institute, University of Agriculture Faisalabad.

\section{Collect and rearing the test culture insect}

Different and diverse age T.castaneum and T.granarium will be collected through grain market which is situated in Faisalabad. The population for all of the tow insect assimilate to the laboratory and $1.5 \mathrm{~kg}$ capacity having commodity in plastic jars ( firstly decontaminate the store grains for T.granarium and store grain flour for T.castaneum, it can decontaminate for 30 minutes in $70{ }^{\circ} \mathrm{C}$ through the oven ( Lab Line Instrument Inc. Model No.3512-1) and it shielded through muslin cloths. Both insects' after three days from commodity adults will be sieved out. Target insects can have eggs which can be sieved commodities, will be placed in jars and it can place in an optimal condition $\left(65 \pm 5 \%\right.$ R.H. and $\left.30 \pm 2{ }^{\circ} \mathrm{C}\right)$ and it can be homogeneous and also getting the $\mathrm{F}_{1}$ population (Hbib-urRehman, 2018). Bottles will be removed after 3 days then shift the bottles into new jars, the floor left behind will contain the eggs, hatching time period is near about 3 to 5 days [18].

To raise homogenous population pupa of the same age will be collected during rearing of insect and in separate plastic jars for adult emergence (2 weeks) [18].Firstly we can collect the leaves of $R$. communis, Jatropha curcus and Citrus paradise from different localities in Faisalabad, The identified samples were bought to the Department of Chemistry, Punjab Bioenergy Institute for further work. The sample leaves was thoroughly washed with tap water followed by distilled water to remove the impurities [19].

The wet plant leaves were kept on shade for 25 days and put in air dry.Dried leaves will be converted into powder form through the electrical grinder (Pascal engineering Co. ltd., Gatwick road crawley Sussex, England) and it will be sieved through a mesh (40mm) then we acquire a fine powder form [20]After shading, drying and grinding, 50g of Ricinus communis leaves powder material extract were put in the Soxlet apparatus by dipping or mixing $100 \mathrm{ml}$ of the methanol, chloroform, petroleum ether and n-hexane for 24 hours at 220 revolution per minute [21]. For the storage of plant powder we were used the opaquae screw caped air tight containers, which would make them moisture free. After this containers were kept at room temperature for further use. The samples were also being stored in refrigerator at $4{ }^{\circ} \mathrm{C}$. We can form different concentration such as $8 \%, 10.0 \%$ and $12 \%$ from the stock solution of each plant [22]. We were use the filter paper dip method. As an exposure chamber we can use the petri dish. In each petri dish, can placed the $5 \mathrm{~cm}$ in diameter paper. Ethanol mixed extract R. communis, Jatropha curcus and Citrus paradise were used. Through the use of syringe required concentration of botanical extracts sprayed on the filter paper which is placed on the petri dish. We can give 20 pupa of T.granarium and T.castaneum was put in each petri dish on the filter paper sprayed with different concentration of extracts. For the prevention of run out of pupas on the dish, we can cover the petri dish with lid [23]

\section{BIOSYNTHESIS OF NANOPARTICLE}


Silver nitrate, titanium oxide, Magnesium oxide and Zinc oxide used in this study, will be obtained from Punjab Bioenergy Institute Laboratory, Agriculture University, Faisalabad.

\section{Preparation of silver Nano-particles}

Firstly we can prepare the silver Nano particle like this way, Take the leaves powder from R.communis, Jatropha curcus, Citrus paradise purchased from the local market. Deionized water used in all experiments, I took $10 \mathrm{~g}$ of $R$. communis, Jatropha curcus and Citrus paradise extracts by using weight balance, which can be boiled in $100 \mathrm{ml}$ distill water in $250 \mathrm{ml}$ conical flask. Then this extract were cooled at room temperature, filter through Whatmans No. 1 filter paper. This filtrate was an act of reducing and stabilizing agent for the synthesis of Silver nanoparticles [23]Ammonium solution will be added to AgNO3 (solution followed by addition of plant material extract $1-10 \mathrm{ml}$ ) as described in [24]

\section{Preparation of Zinc oxide Nano-particles}

Firstly we can prepare the silver Nano particle like this way, Take the leaves powder from R.communis, Jatropha curcus, Citrus paradise purchased from the local market. Deionized water used in all experiments, I took $10 \mathrm{~g}$ of $R$. communis, Jatropha curcus and Citrus paradise extracts by using weight balance, which can be boiled in $100 \mathrm{ml}$ distill water in $250 \mathrm{ml}$ conical flask. Then this extract were cooled at room temperature, filter through Whatmans No. 1 filter paper. This filtrate was an act of reducing and stabilizing agent for the synthesis of zinc oxide nanoparticles. Ammonium solution will be added to $\mathrm{ZnO}$ (solution followed by addition of plant material extract $1-10 \mathrm{ml}$ ) as described in [25].

\section{Bioassay of Zinc Oxide}

Zinc oxide was synthesized by using green synthesis method. $5 \mathrm{ml}$ solution of plant extracts oil from the stock solution mixed in $50 \mathrm{ml}$ of distilled water, heated at $80^{\circ} \mathrm{C}$ for 30 minutes at hot plate. We can add the $10 \mathrm{ml}$ plant extract (oil +Distill water) in $1.5 \mathrm{M}$ solution of zinc nitrate hex hydrate. The salt solution of different concentration $(0.5-2.5 \mathrm{M})$ was used. The $\mathrm{pH}$ maintained 7-9 by adding the ammonia solution. The solution mixture was boiled at $60-80^{\circ} \mathrm{C}$ or $400 \mathrm{rpm}$ stirring till the color would be changed to yellow paste form. Then this paste were transferred into a crucible, which was kept on furnace at $400^{\circ} \mathrm{C}$ for 2 hours until the color of the precipitates changed into light yellow to white color. Then this precipitates were grinded and stored for further analysis [26].

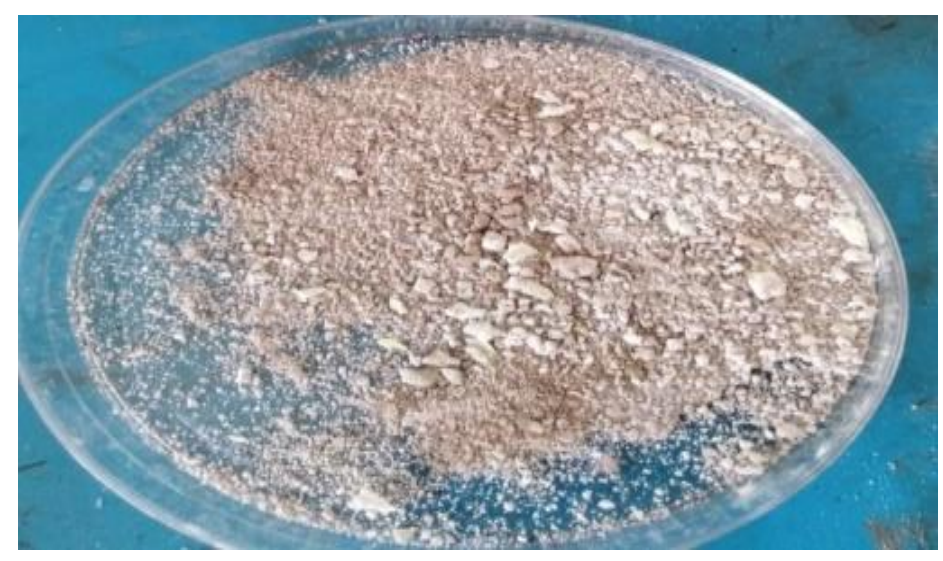

Zinc-Oxide Dried nano-composits)

Change in color of solution during formation of zinc oxide nanoparticles by using Jatropha curcus, Citrus paradise and R. communis plant extracts.

\begin{tabular}{|c|c|c|c|c|}
\hline Solution & Before Reduction & After Reduction & Color intensity & Time \\
\hline Jatropha curcus & Dark Yellow & & & \\
\hline $\begin{array}{c}\text { 1.5M zinc nitrate } \\
\text { hex hydrate }\end{array}$ & Transparent & Pale Yellow & + & Immediately \\
\hline & & Yellowish white & ++ & After 7 hours \\
\hline
\end{tabular}




\begin{tabular}{|c|c|c|c|c|}
\hline & & White & ++ & After 24 hours \\
\hline $\begin{array}{c}\text { Citrus paradise } \\
\text { hex hydrate }\end{array}$ & Lite Yellow & & + & Immediately \\
\hline & Transparent & Dark Yellow & ++ & After 7 hours \\
\hline $\begin{array}{c}\text { R. communis } \\
\text { hex hydrate }\end{array}$ & Transparent & Pale Yellow & +++ hours \\
\hline & & Lite Gray white & + & Immediately \\
\hline
\end{tabular}

\section{RESULTS}

Current details and studies were planned to give the explanations about the toxicity, growth inhibitory activities and repellent of Jatropha curcus ,Citrus paradise and R. communis against T.castaneum and T.granarium under there laboratory conditions. We can conduct the experiments under specialized designs Completely Randomized Design (CRD) with all different treatments were replicated in thrice along with the control factor. Plants extracts were used at three different types of concentrations i.e., 5, 10 and 15 $\%$, data will be regarding mortality were observed after 24, 48 and 72 hours of treatment application. At same application type/rate of plants extracts we were conducted the repellency experiments and growth inhibition individually. The data were collected regarding larval inhibition, pupa; inhibition and adult inhibition after regular intervals, while the repellency data was recorded after 24 hrs.

\section{MORTALITY DATA AFTER EXPOSURE OF 24 HRS}

Table 1 reveals the analysis of variance (ANOVA) of data regarding mean percentage mortality of $T$. castaneum at different concentrations of Jatropha curcus ,Citrus paradise and R. communis. Data showed that main effects, plants $(\mathrm{F}=4.66 ; \mathrm{df}=1$ : $\mathrm{p}<0.05)$ and concentration $(\mathrm{F}=11.10 \mathrm{df}=; 2 \mathrm{p}<0.05)$ were significant regarding mortality values of $T$. castaneum after exposure period of 24 hours.

Table 1. Analysis of variance (ANOVA) of the data concerning \% mortality of Tribolium castaneum (Herbst) for different plant extracts

\begin{tabular}{|c|c|c|c|c|}
\hline S.O.V & DF & SS & MSS & F value \\
\hline Plant & 3 & 293.667 & 97.222 & $11.12^{* *}$ \\
\hline Concentration & 2 & 463.500 & 233.250 & $1.576^{*}$ \\
\hline Plant*Concentration & 6 & 70.843 & 11.87 & 20.843 \\
\hline Error & 24 & 500.000 & 1326.000 & \\
\hline
\end{tabular}

Table 2. Comparison of the mean percentage mortality of Tribolium castaneum after exposure to different concentrations of plant extracts after $24 \mathrm{hrs}$ 


\begin{tabular}{|c|r|}
\hline Concentrations (\%) & Mean percentage mortality \pm SE \\
\hline $\mathbf{5}$ & $4.68 \pm 1.43 \mathrm{c}$ \\
\hline $\mathbf{1 0}$ & $9.37 \pm 1.29 \mathrm{~b}$ \\
\hline $\mathbf{1 5}$ & $13.40 \pm 1.66 \mathrm{a}$ \\
\hline
\end{tabular}

The mean mortality was $4.68 \%$ at $5 \%$ concentration and $13.40 \%$ mortality was observed at $15 \%$ concentration of the plant extracts. From results we can conclude that concentration has significant effect on percent mean percent mortality of T. castaneum.

4.3 Comparison of the mean percentage mortality of Tribolium castaneum after exposure to different plant extracts after 24 hrs Table 4.3 for percent mean mortality values of different plant extracts at different concentration levels showed that extracts of $R$. communis and Jatropha curcus gave mortality values 12.23 and $11.65 \%$,correspondly. While least mortality $5.57 \%$ was given by extract of Citrus paradise.

4. Comparative mean percentage mortality of Tribolium castaneum after exposure to different concentrations of plant extracts after $24 \mathrm{hrs}$.

\begin{tabular}{|c|c|}
\hline Plant extracts x Concentrations (\%) & (\%) Mean Mortality $\mathbf{S E}$ \\
\hline Citrus paradise x 5 & $1.77 \pm 0.09 \mathrm{~d}$ \\
\hline Citrus paradise x 10 & $8.04 \pm 1.75 \mathrm{c}$ \\
\hline Citrus paradise x 15 & $11.26 \pm 2.64 \mathrm{bc}$ \\
\hline Jatropha curcus x 5 & $5.02 \pm 1.91 \mathrm{~cd}$ \\
\hline Jatropha curcus x 10 & $13.76 \pm 3.03 \mathrm{bc}$ \\
\hline Jatropha curcus x 15 & $18.44 \pm 3.12 \mathrm{a}$ \\
\hline Ricinus communis x 5 & $10.22 \pm 1.96 \mathrm{bc}$ \\
\hline Ricinus communis x 10 communis x 15 & $14.73 \pm 3.39 \mathrm{ab}$ \\
\hline
\end{tabular}

Table 4 showed that maximum mortality $18.34 \%$ was observed with $15 \%$ concentration of Jatropha curcus after exposure of 24 hr followed 15.00 with extract of Ricinus communis and g Citrus paradise are $11.16 \%$ at same concentrations. Mean percentage mortality of $10.12 \%$ was recorded at $5 \%$ concentration of Ricinus communis, followed by Jatropha curcus 5.01\%. Minimum mean mortaliy $1.67 \%$ was given by Citrus paradise at $5 \%$ concentration, respectively. The mean mortality was found $14.63,13.67 \%$ in case of Ricinus communis and Jatropha curcus at $10 \%$ concentration of plant extract. From results we concluded that there was a gradually increase in mortality values with increase in concentration of plant extracts.

\section{MORTALITY DATA AFTER EXPOSURE OF 48 HRS}

Table 45 reveals the analysis of variance (ANOVA) of data regarding mean percentage mortality of $T$. castaneum at different concentrations of Jatropha curcus, Ricinus communis and Citrus paradise. Data showed that main effects, plants $(\mathrm{F}=12.2602$; $\mathrm{df}=1$ : $\mathrm{p}<0.05)$ and concentration $(\mathrm{F}=11.4878 \mathrm{df}=; 2 \mathrm{p}<0.05)$ were significant regarding mortality values of $T$. castaneum after exposure period of 48 hours 
Table 5 Analysis of variance (ANOVA) of the data concerning \% mortality of Tribolium castaneum (Herbst) for different plant extracts

\begin{tabular}{|c|c|c|c|c|}
\hline S.O.V & DF & SS & MSS value & 349.07 \\
\hline Plant & 3 & 1047.22 & 327.08 & $11.4878^{* *}$ \\
\hline Concentration & 2 & 654.17 & 15.05 & $1.5285^{*}$ \\
\hline Plant*Concentration & 6 & 90.28 & & \\
\hline Error & 24 & 683.33 & & \\
\hline Total & 35 & 204.86 & & \\
\hline
\end{tabular}

$$
\text { NS = Non-significant }(\mathrm{P}>0.05) ; * \text { Significant }(\mathrm{P}<0.05) ; * *=\text { Highly significant }(\mathrm{P}<0.01)
$$

Table 6 Comparison of the mean percentage mortality of Tribolium castaneum after exposure to different concentrations of plant extracts after $24 \mathrm{hrs}$

\begin{tabular}{|c|c|}
\hline Concentrations (\%) & Mean percentage mortality \pm SE \\
\hline $\mathbf{5}$ & $13.75 \pm 1.95 \mathrm{c}$ \\
\hline $\mathbf{1 0}$ & $19.58 \pm 1.89 \mathrm{~b}$ \\
\hline $\mathbf{1 5}$ & $24.16 \pm 2.56 \mathrm{a}$ \\
\hline
\end{tabular}

Data table 6 showed that mortality $13.75 \%$ mean percentage mortality was observed at $5 \%$ concentration and $24.16 \%$ mortality was observed at $15 \%$ concentration of the plant extracts. From results we can conclude that concentration has significant effect on percent mean percent mortality of $T$. castaneum.

7 Comparison of the mean percentage mortality of Tribolium castaneum after exposure to different plant extracts after 48 hrs.

\begin{tabular}{|c|c|}
\hline Concentrations (\%) & (\%) Mean Mortality \pm SE \\
\hline Jatropha curcus & $23.32 \pm 2.63 \mathrm{a}$ \\
\hline Ricinus communis & $25.54 \pm 2.42 \mathrm{a}$ \\
\hline Citrus paradise & $15.01 \pm 1.86 \mathrm{~b}$ \\
\hline
\end{tabular}

Table 7 showed percent mean mortality values of different plant extracts at different concentration levels. Extracts of Ricinus communis and Jatropha curcus gave mortality values 25.54 and $23.32 \%$, correspondly. While least mortality $15.01 \%$ was given by extract of Citrus paradise.

8 Comparative mean percentage mortality of Tribolium castaneum after exposure to different concentrations of plant extracts after 48 hrs
Plant extracts $x$ Concentrations (\%)
(\%) Mean Mortality \pm SE 


\begin{tabular}{|c|c|}
\hline Plant extracts x Concentrations (\%) & (\%) Mean Mortality \pm SE \\
\hline Citrus paradise x 5 & $10.02 \pm 2.88$ \\
\hline Citrus paradise $\times 10$ & $11.16 \pm 1.66$ \\
\hline Citrus paradise $\mathrm{x} 15$ & $16.65 \pm 2.64$ \\
\hline Jatropha curcus x 5 & $14.01 \pm 2.88$ \\
\hline Jatropha curcus $\mathrm{x} 10$ & $25.06 \pm 2.92$ \\
\hline Jatropha curcus $\times 15$ & $29.34 \pm 2.89$ \\
\hline Ricinus communis $\mathrm{x} 5$ & $21.66 \pm 1.66 \mathrm{bc}$ \\
\hline Ricinus communis x 10 & $24.32 \pm 3.38 \mathrm{ab}$ \\
\hline Ricinus communis x 15 & $31.67 \pm 3.40 \mathrm{ab}$ \\
\hline
\end{tabular}

Table 8 revealed that maximum mortality $31.67 \%$ was observed with $15 \%$ concentration of Ricinus communis after exposure of 48 hr followed $29.34 \%$ with extract of Jatropha curcus, Citrus paradise gave 16.65 at $15 \%$ concentrations. Mean percentage mortality of $21.66 \%$ was recorded at $5 \%$ concentration of Ricinus communis followed by Jatropha curcus $14.01 \%$. Minimum mean mortaliy 10.02 $\%$ was given by Citrus paradise at 5\% concentration, respectively. The mean mortality was found 25.06 and $24.32 \%$ in case of Jatropha curcus and Ricinus communis, respectively at $10 \%$ concentration of plant extract. From results we concluded that there was a gradually increase in mortality values with increase in concentration of plant extracts.

\section{MORTALITY DATA AFTER EXPOSURE OF 72 HRS}

Table 4.9 reveals the analysis of variance (ANOVA) of data regarding mean percentage mortality of $T$. castaneum at different concentrations of Jatropha curcus , Ricinus communis and Citrus paradise. Data showed that main effects, plants ( $\mathrm{F}=4.66$; $\mathrm{df}=1$ : $\mathrm{p}<0.05)$ and concentration $(\mathrm{F}=11.10 \mathrm{df}=; 2 \mathrm{p}<0.05)$ were significant regarding mortality values of $T$. castaneum after exposure period of 72 hours.

Table 9. Analysis of variance (ANOVA) of the data concerning \% mortality of Tribolium castaneum (Herbst) for different plant

\begin{tabular}{|c|c|c|c|c|}
\hline S.O.V & DF & MSS & F value \\
\hline Plant & 3 & 2054.07 & 684.69 & 1628.94 \\
\hline Concentration & 2 & 3257.89 & 90.93 & $19.0000^{* *}$ \\
\hline Plant*Concentration & 6 & 545.58 & $2.0706^{*}$ \\
\hline Error & 24 & 2057.61 & & \\
\hline Total & 35 & 7915.15 & & \\
\hline
\end{tabular}

NS = Non-significant $(\mathrm{P}>0.05) ; *$ Significant $(\mathrm{P}<0.05) ; * *=$ Highly significant $(\mathrm{P}<0.01)$ 


\section{WITH ZnO NANO-PARTICALS against Tribolium castanium}

\section{MORTALITY DATA AFTER EXPOSURE OF 24 HRS}

To evaluate the mortality of $T$. castaneum, homogenous adults were released on treated diet in small plastic jars. Adults were allowed to feed on treated diet and data regarding mortality was recorded. Wheat grains were used as diet and three concentrations of each plant extract were used viz., 5, 10 and $15 \%$. Mortality data was recorded for 24,48 and $72 \mathrm{~h}$ of exposure period. For mortality assessment insects were kept in incubators at $30 \pm 2{ }^{\circ} \mathrm{C}$ and $60 \pm 5 \% \mathrm{RH}$. Each treatment and control were replicated three times.

Table 4.1 reveals the analysis of variance (ANOVA) of data regarding mean percentage mortality of $T$. castaneum at different concentrations of Jatropha curcus ,Citrus paradise and $R$. communis. Data showed that main effects, plants $(\mathrm{F}=4.66 ; \mathrm{df}=1: \mathrm{p}<0.05)$ and concentration $(\mathrm{F}=11.10 \mathrm{df}=; 2 \mathrm{p}<0.05)$ were significant regarding mortality values of $T$. castaneum after exposure period of 24 hours.

13. Analysis of variance (ANOVA) of the data concerning $\%$ mortality of Tribolium castaneum (Herbst) for ZnO based nano-particals

\begin{tabular}{|c|c|c|c|c|}
\hline S.O.V & DF & SS & MSS & F value \\
\hline Plant & 2 & 2137.520 & 1068.760 & $54.1791^{* *}$ \\
\hline Concentration(Conc.) & 2 & 1438.431 & 719.215 & $36.4594^{* *}$ \\
\hline Plant*Concentration & 4 & 400.542 & 100.136 & $5.0762^{*}$ \\
\hline Error & 18 & 355.076 & 19.726 & \\
\hline Total & 26 & 4331.569 & & \\
\hline
\end{tabular}

Table 14. Comparison of the mean percentage mortality of Tribolium castaneum after exposure to different concentrations of plant extracts after $24 \mathrm{hrs}$

\begin{tabular}{|c|c|}
\hline Concentrations (\%) & Mean percentage mortality \pm SE \\
\hline $\mathbf{5}$ & $9.16 \pm 1.99 \mathrm{c}$ \\
\hline $\mathbf{1 0}$ & $18.09 \pm 3.35 \mathrm{~b}$ \\
\hline $\mathbf{1 5}$ & $27.04 \pm 4.99 \mathrm{a}$ \\
\hline
\end{tabular}

Data in table 2. represents the insecticidal effect of different concentrations of 3 different oil against Tribolium castaneum. The experimental data revealed that maximum mortality $(27.04 \%)$ at $15 \%$ was recorded. The mean mortality was $18.09 \%$ at $10 \%$ concentration and $9.16 \%$ mortality was observed at $5 \%$ concentration of the plant extracts. From this it is concluded that mortality only increased with increase in concentrations of the 3 different plant oil and also shows that concentration has significant effect on percent mean percent mortality of $T$. castaneum.

15 Comparison of the mean percentage mortality of Tribolium castaneum after exposure to different plant extracts after 24 hrs

\begin{tabular}{|c|c|}
\hline Concentrations (\%) & Mean percentage mortality \pm SE \\
\hline P1 & $8.34 \pm 1.67 \mathrm{c}$ \\
\hline
\end{tabular}




\begin{tabular}{|c|r|}
\hline Concentrations (\%) & Mean percentage mortality \pm SE \\
\hline P2 & $16.12 \pm 2.16 \mathrm{~b}$ \\
\hline P3 & $29.85 \pm 4.79 \mathrm{a}$ \\
\hline
\end{tabular}

Table 4.3 for percent mean mortality values of different plant extracts at different concentration levels showed that extracts of $R$. communis and Jatropha curcus gave mortality values 29.85 and $16.12 \%$,correspondly. While least mortality $8.34 \%$ was given by extract of Citrus paradise.

16 Comparative mean percentage mortality of Tribolium castaneum after after $24 \mathrm{hrs}$

\begin{tabular}{|c|c|}
\hline Plant extracts x Concentrations (\%) & (\%) Mean Mortality \pm SE \\
\hline Citrus paradise $\mathrm{x} 5$ & $3.34 \pm 1.67 \mathrm{~g}$ \\
\hline Citrus paradise $\mathrm{x} 10$ & $8.34 \pm 1.67$ efg \\
\hline Citrus paradise $\mathrm{x} 15$ & $13.34 \pm 1.67 \mathrm{def}$ \\
\hline Jatropha curcus x 5 & $8.34 \pm 1.67 \mathrm{fg}$ \\
\hline Jatropha curcus $\mathrm{x} 10$ & $18.34 \pm 1.67 \mathrm{~cd}$ \\
\hline Jatropha curcus $\mathrm{x} 15$ & $21.67 \pm 1.67 \mathrm{bc}$ \\
\hline Ricinus communis x 5 & $15.82 \pm 1.68 \mathrm{de}$ \\
\hline Ricinus communis $\mathrm{x} 10$ & $27.69 \pm 6.06 \mathrm{~b}$ \\
\hline Ricinus communis $\times 15$ & $46.12 \pm 1.68 \mathrm{a}$ \\
\hline
\end{tabular}

Table 4. showed the interaction between different concentrations (5, 10 and 15\%) and different exposure time period. Mean mortality of $T$. castaneum was given in percentage by the application of extract of Ricinus communis, Jatropha curcus, Citrus paradise oil along with standard error in table 4.

Mean comparison of percentage mortality values of $T$. castaneum at different concentrations of selected plant extract were highest at maximum concentration. Extract of Ricinus communis gave the highest mean mortality revealed that maximum mortality (46.12 \%) at $15 \%$ was recorded. The mean mortality was $27.60 \%$ at $10 \%$ concentration and $15.82 \%$ mortality was observed at $5 \%$ concentration of the plant extracts. Extract of Jatropha curcus gave the mean mortality revealed that maximum mortality $(21.67 \%)$ at $15 \%$ was recorded. The mean mortality was $18.34 \%$ at $10 \%$ concentration and $8.34 \%$ mortality was observed at $5 \%$ concentration of the plant extracts. Extract of Citrus paradise gave the mean mortality revealed that maximum mortality $(13.34 \%)$ at $15 \%$ was recorded. The mean mortality was $8.34 \%$ at $10 \%$ concentration and $3.34 \%$ mortality was observed at $5 \%$ concentration of the plant extracts.The given outcome showed that interaction of exposure time and concentration was significant. From results we concluded that there was a gradually increase in mortality values with increase in concentration of plant extracts.

\section{MORTALITY DATA AFTER EXPOSURE OF 48 HRS}


Table 17. Analysis of variance (ANOVA) of the data concerning \% mortality of Tribolium castaneum (Herbst) for ZnO based nanoparticals

\begin{tabular}{|c|c|c|c|c|}
\hline S.O.V & DF & SS & MSS value \\
\hline Plant & 2 & 2093.50 & 1046.75 & $65.5597 * *$ \\
\hline Concentration(Conc.) & 2 & 2732.05 & 1366.03 & 104.66 \\
\hline Plant*Concentration & 4 & 418.65 & 15.97 \\
\hline Error & 18 & 287.39 & $6.5552^{*}$ \\
\hline Total & 26 & 5531.59 & & \\
\hline
\end{tabular}

Table 18. Comparison of the mean percentage mortality of Tribolium castaneum after exposure to different concentrations of plant extracts after $48 \mathrm{hrs}$

\begin{tabular}{|c|r|}
\hline Concentrations (\%) & Mean percentage mortality \pm SE \\
\hline $\mathbf{5}$ & $11.95 \pm 1.33 \mathrm{c}$ \\
\hline $\mathbf{1 0}$ & $22.54 \pm 1.33 \mathrm{~b}$ \\
\hline $\mathbf{1 5}$ & $36.51 \pm 1.33 \mathrm{a}$ \\
\hline
\end{tabular}

Data in table 18. represents the insecticidal effect of different concentrations of 3 different oil against Tribolium castaneum. The experimental data revealed that maximum mortality $(36.51 \%)$ at $15 \%$ was recorded. The mean mortality was $22.54 \%$ at $10 \%$ concentration and $11.95 \%$ mortality was observed at $5 \%$ concentration of the plant extracts. From this it is concluded that mortality only increased with increase in concentrations of the 3 different plant oil and also shows that concentration has significant effect on percent mean percent mortality of $T$. castaneum.

19 Comparison of the mean percentage mortality of Tribolium castaneum after exposure to different plant extracts after 48 hrs

\begin{tabular}{|c|r|}
\hline Concentrations (\%) & Mean percentage mortality \pm SE \\
\hline P1 & $12.77 \pm 2.51 \mathrm{c}$ \\
\hline P2 & $23.89 \pm 3.31 \mathrm{~b}$ \\
\hline P3 & $34.34 \pm 5.51 \mathrm{a}$ \\
\hline
\end{tabular}

Table 4.19. for percent mean mortality values of different plant extracts at different concentration levels showed that extracts of $R$. communis and Jatropha curcus gave mortality values 34.34 and $23.89 \%$,correspondly. While least mortality $12.77 \%$ was given by extract of Citrus paradise.

20 Comparative mean percentage mortality of Tribolium castaneum after exposure to different concentrations of plant extracts after $48 \mathrm{hrs}$ 


\begin{tabular}{|c|c|}
\hline Plant extracts x Concentrations (\%) & (\%) Mean Mortality \pm SE \\
\hline Citrus paradise $\mathrm{x} 5$ & $5.00 \pm 0.00 \mathrm{~g}$ \\
\hline Citrus paradise $\mathrm{x} 10$ & $11.67 \pm 1.67 \mathrm{efg}$ \\
\hline Citrus paradise $\mathrm{x} 15$ & $21.67 \pm 1.67 \mathrm{def}$ \\
\hline Jatropha curcus $\times 5$ & $11.67 \pm 1.67 \mathrm{fg}$ \\
\hline Jatropha curcus $\mathrm{x} 10$ & $26.67 \pm 1.67 \mathrm{~cd}$ \\
\hline Jatropha curcus $\mathrm{x} 15$ & $33.33 \pm 1.67 \mathrm{bc}$ \\
\hline Ricinus communis $\mathrm{x} 5$ & $19.19 \pm 0.00 \mathrm{de}$ \\
\hline Ricinus communis $\mathrm{x} 10$ & $29.29 \pm 2.91 \mathrm{~b}$ \\
\hline Ricinus communis $\mathrm{x} 15$ & $54.54 \pm 5.05 \mathrm{a}$ \\
\hline
\end{tabular}

Table 20. showed the interaction between different concentrations (5,10 and 15\%) and different exposure time period. Mean mortality of $T$. castaneum was given in percentage by the application of extract of Ricinus communis, Jatropha curcus, Citrus paradise oil along with standard error in table 20.

Mean comparison of percentage mortality values of $T$. castaneum at different concentrations of selected plant extract were highest at maximum concentration. Extract of Ricinus communis gave the highest mean mortality revealed that maximum mortality $(54.54 \%)$ at $15 \%$ was recorded. The mean mortality was $29.29 \%$ at $10 \%$ concentration and $19.19 \%$ mortality was observed at $5 \%$ concentration of the plant extracts. Extract of Jatropha curcus gave the mean mortality revealed that maximum mortality (33.33\%) at $15 \%$ was recorded. The mean mortality was $26.67 \%$ at $10 \%$ concentration and $11.67 \%$ mortality was observed at $5 \%$ concentration of the plant extracts. Extract of Citrus paradise gave the mean mortality revealed that maximum mortality (21.67\%) at $15 \%$ was recorded. The mean mortality was $11.67 \%$ at $10 \%$ concentration and $5.00 \%$ mortality was observed at $5 \%$ concentration of the plant extracts. The given outcome showed that interaction of exposure time and concentration was significant. From results we concluded that there was a gradually increase in mortality values with increase in concentration of plant extracts.

\section{MORTALITY DATA AFTER EXPOSURE OF 72 HRS}

Table 21. Analysis of variance (ANOVA) of the data concerning \% mortality of Tribolium castaneum (Herbst) for $\mathrm{ZnO}$ based nanoparticles

\begin{tabular}{|c|c|c|c|c|}
\hline S.O.V & DF & SS & MSS & F value \\
\hline Plant & 2 & 3675.23 & 1837.62 & $196.074^{* *}$ \\
\hline Concentration & 2 & 3386.81 & 1693.40 & $180.686^{* *}$ \\
\hline Plant*Concentration & 4 & 1354.42 & 338.61 & $36.129^{*}$ \\
\hline Error & 18 & 168.70 & 9.37 & \\
\hline
\end{tabular}




\begin{tabular}{|c|c|c|c|c|}
\hline S.O.V & DF & SS & MSS value & F \\
\hline Total & 26 & 8585.16 & & \\
\hline
\end{tabular}

Table 22. Comparison of the mean percentage mortality of Tribolium castaneum after exposure to different concentrations of plant extracts after $72 \mathrm{hrs}$

\begin{tabular}{|c|c|}
\hline Concentrations (\%) & Mean percentage mortality \pm SE \\
\hline $\mathbf{5}$ & $10.28 \pm 1.99 \mathrm{c}$ \\
\hline $\mathbf{1 0}$ & $22.55 \pm 3.14 \mathrm{~b}$ \\
\hline $\mathbf{1 5}$ & $37.66 \pm 7.63 \mathrm{a}$ \\
\hline
\end{tabular}

Data in table 22. represents the insecticidal effect of different concentrations of 3 different oil against Tribolium castaneum. The experimental data revealed that maximum mortality $(37.66 \%)$ at $15 \%$ was recorded. The mean mortality was $22.55 \%$ at $5 \%$ concentration and $10.28 \%$ mortality was observed at $10 \%$ concentration of the plant extracts. From this it is concluded that mortality only increased with increase in concentrations of the 3 different plant oil and also shows that concentration has significant effect on percent mean percent mortality of $T$. castaneum.

23 Comparison of the mean percentage mortality of Tribolium castaneum after exposure to different plant extracts after 24 hrs

\begin{tabular}{|c|c|}
\hline Concentrations (\%) & Mean percentage mortality \pm SE \\
\hline P1 & $10.56 \pm 1.54 \mathrm{c}$ \\
\hline P2 & $21.12 \pm 3.51 \mathrm{~b}$ \\
\hline $\mathbf{P 3}$ & $38.83 \pm 7.31 \mathrm{a}$ \\
\hline
\end{tabular}

Table 4.23 for percent mean mortality values of different plant extracts at different concentration levels showed that extracts of $R$. communis and Jatropha curcus gave mortality values 38.83 and $21.12 \%$,correspondly. While least mortality $10.56 \%$ was given by extract of Citrus paradise.

24. Comparative mean percentage mortality of Tribolium castaneum after exposure to different concentrations of plant extracts after $24 \mathrm{hrs}$

\begin{tabular}{|c|c|}
\hline Plant extracts x Concentrations (\%) & (\%) Mean Mortality \pm SE \\
\hline Citrus paradise x 5 & $5.00 \pm 0.00 \mathrm{~g}$ \\
\hline Citrus paradise x 10 & $11.67 \pm 1.67 \mathrm{efg}$ \\
\hline Citrus paradise x 15 & $15.00 \pm 0.00 \mathrm{def}$ \\
\hline
\end{tabular}




\begin{tabular}{|c|c|}
\hline Plant extracts x Concentrations (\%) & (\%) Mean Mortality \pm SE \\
\hline Jatropha curcus $\times$ 5 & $8.33 \pm 1.67 \mathrm{fg}$ \\
\hline Jatropha curcus $\times 10$ & $23.33 \pm 1.67 \mathrm{~cd}$ \\
\hline Jatropha curcus $\times 15$ & $31.67 \pm 1.67 \mathrm{bc}$ \\
\hline Ricinus communis $\times 5$ & $17.50 \pm 1.68 \mathrm{de}$ \\
\hline Ricinus communis $\times 10$ & $32.65 \pm 1.68 \mathrm{~b}$ \\
\hline
\end{tabular}

Table 24. showed the interaction between different concentrations $(5,10$ and $15 \%)$ and different exposure time period. Mean mortality of $T$. castaneum was given in percentage by the application of extract of Ricinus communis, Jatropha curcus, Citrus paradise oil along with standard error in table 24.

Mean comparison of percentage mortality values of $T$. castaneum at different concentrations of selected plant extract were highest at maximum concentration. Extract of Ricinus communis gave the highest mean mortality revealed that maximum mortality $(66.32 \%)$ at $15 \%$ was recorded. The mean mortality was $32.65 \%$ at $10 \%$ concentration and $17.50 \%$ mortality was observed at $5 \%$ concentration of the plant extracts. Extract of Jatropha curcus gave the mean mortality revealed that maximum mortality $(31.67 \%)$ at $15 \%$ was recorded. The mean mortality was $23.33 \%$ at $10 \%$ concentration and $8.33 \%$ mortality was observed at $5 \%$ concentration of the plant extracts. Extract of Citrus paradise gave the mean mortality revealed that maximum mortality $(15.00 \%)$ at $15 \%$ was recorded. The mean mortality was $11.67 \%$ at $10 \%$ concentration and $5.00 \%$ mortality was observed at $5 \%$ concentration of the plant extracts.The given outcome showed that interaction of exposure time and concentration was significant. From results we concluded that there was a gradually increase in mortality values with increase in concentration of plant extracts.

\section{WITH ZnO NANO-PARTICALS against Trogoderma granarium} MORTALITY DATA AFTER EXPOSURE OF 24 HRS

Table 25. Analysis of variance (ANOVA) of the data concerning \% mortality of Trogoderma granarium (Herbst) for $\mathrm{ZnO}$ based nanoparticles

\begin{tabular}{|c|c|c|c|c|}
\hline S.O.V & DF & SS & MSS & F value \\
\hline Plant & 2 & 994.669 & 497.334 & $58.8831^{* *}$ \\
\hline Concentration & 2 & 881.393 & 440.697 & $52.1773^{* *}$ \\
\hline Plant*Concentration & 4 & 166.266 & 41.566 & $4.9214^{*}$ \\
\hline Error & 18 & 152.030 & 8.446 & \\
\hline Total & 26 & 2194.358 & & \\
\hline
\end{tabular}

Table 26. Comparison of the mean percentage mortality of Trogoderma granarium after exposure to different concentrations of plant extracts after $24 \mathrm{hrs}$ 


\begin{tabular}{|c|r|}
\hline Concentrations (\%) & Mean percentage mortality \pm SE \\
\hline $\mathbf{5}$ & $6.36 \pm 1.31 \mathrm{c}$ \\
\hline $\mathbf{1 0}$ & $12.51 \pm 2.54 \mathrm{~b}$ \\
\hline $\mathbf{1 5}$ & $20.33 \pm 3.16 \mathrm{a}$ \\
\hline
\end{tabular}

Data in table 26 represents the insecticidal effect of different concentrations of 3 different oil against Trogoderma granarium. The experimental data revealed that maximum mortality $(20.33 \%)$ at $15 \%$ was recorded. The mean mortality was $6.36 \%$ at $5 \%$ concentration and $12.51 \%$ mortality was observed at $10 \%$ concentration of the plant extracts. From this it is concluded that mortality only increased with increase in concentrations of the 3 different plant oil and also shows that concentration has significant effect on percent mean percent mortality of $T$. granarium.

27 Comparison of the mean percentage mortality of Trogoderma granarium after hrs exposure to different plant extracts after 24

\begin{tabular}{|c|r|}
\hline Concentrations (\%) & Mean percentage mortality \pm SE \\
\hline P1 & $7.23 \pm 1.68 \mathrm{c}$ \\
\hline P2 & $10.56 \pm 1.54 \mathrm{~b}$ \\
\hline P3 & $21.43 \pm 3.37 \mathrm{a}$ \\
\hline
\end{tabular}

Table 27 for percent mean mortality values of different plant extracts at different concentration levels showed that extracts of $R$. communis and Jatropha curcus gave mortality values 21.43 and $10.56 \%$,correspondly. While least mortality $7.23 \%$ was given by extract of Citrus paradise.

28. Comparative mean percentage mortality of Trogoderma granarium after exposure to different concentrations of plant extracts after $24 \mathrm{hrs}$

\begin{tabular}{|c|c|}
\hline Plant extracts x Concentrations (\%) & (\%) Mean Mortality \pm SE \\
\hline Citrus paradise x 5 & $3.34 \pm 1.67 \mathrm{~g}$ \\
\hline Citrus paradise x 10 & $5.00 \pm 0.00 \mathrm{efg}$ \\
\hline Citrus paradise x 15 & $13.34 \pm 1.67 \mathrm{def}$ \\
\hline Jatropha curcus x 5 & $5.00 \pm 0.00 \mathrm{fg}$ \\
\hline Jatropha curcus x 10 & $11.67 \pm 1.67 \mathrm{~cd}$ \\
\hline Jatropha curcus x 15 & $15.00 \pm 0.00 \mathrm{bc}$ \\
\hline
\end{tabular}




\begin{tabular}{|c|c|}
\hline Plant extracts x Concentrations (\%) & (\%) Mean Mortality \pm SE \\
\hline Ricinus communis x 10 & $20.87 \pm 3.36 \mathrm{~b}$ \\
\hline Ricinus communis x 15 & $32.65 \pm 1.68 \mathrm{a}$ \\
\hline
\end{tabular}

Table 28. showed the interaction between different concentrations (5, 10 and 15\%) and different exposure time period. Mean mortality of $T$. granarium was given in percentage by the application of extract of Ricinus communis, Jatropha curcus, Citrus paradise oil along with standard error in table 28.

Mean comparison of percentage mortality values of $T$. granarium at different concentrations of selected plant extract were highest at maximum concentration. Extract of Ricinus communis gave the highest mean mortality revealed that maximum mortality (32.65\%) at $15 \%$ was recorded. The mean mortality was $20.87 \%$ at $10 \%$ concentration and $10.77 \%$ mortality was observed at $5 \%$ concentration of the plant extracts. Extract of Jatropha curcus gave the mean mortality revealed that maximum mortality (15.00\%) at $15 \%$ was recorded. The mean mortality was $11.67 \%$ at $10 \%$ concentration and $5.00 \%$ mortality was observed at $5 \%$ concentration of the plant extracts. Extract of Citrus paradise gave the mean mortality revealed that maximum mortality $(13.34 \%)$ at $15 \%$ was recorded. The mean mortality was $5.00 \%$ at $10 \%$ concentration and $3.34 \%$ mortality was observed at $5 \%$ concentration of the plant extracts. The given outcome showed that interaction of exposure time and concentration was significant. From results we concluded that there was a gradually increase in mortality values with increase in concentration of plant extracts.

\section{MORTALITY DATA AFTER EXPOSURE OF 48 HRS}

Table 29. Analysis of variance (ANOVA) of the data concerning \% mortality of Trogoderma granarium (Herbst) for ZnO based nanoparticles

\begin{tabular}{|c|c|c|c|c|}
\hline S.O.V & DF & SS & MSS value \\
\hline Plant & 2 & 1535.136 & 767.568 & $117.4032 * *$ \\
\hline Concentration & 2 & 1183.249 & 591.625 & 123.653 \\
\hline Plant*Concentration & 4 & 494.613 & $18.9133 * *$ \\
\hline Error & 18 & 117.682 & 6.538 & \\
\hline
\end{tabular}

Table 30. Comparison of the mean percentage mortality of Trogoderma granarium after exposure to different concentrations of plant extracts after $48 \mathrm{hrs}$

\begin{tabular}{|c|r|}
\hline Concentrations (\%) & Mean percentage mortality \pm SE \\
\hline $\mathbf{5}$ & $6.36 \pm 1.31 \mathrm{c}$ \\
\hline $\mathbf{1 0}$ & $14.18 \pm 2.30 \mathrm{~b}$ \\
\hline
\end{tabular}




\begin{tabular}{|c|c|}
\hline Concentrations (\%) & Mean percentage mortality \pm SE \\
\hline 15 & $22.58 \pm 4.77$ a \\
\hline
\end{tabular}

Data in table 4.30. represents the insecticidal effect of different concentrations of 3 different oil against Trogoderma granarium. The experimental data revealed that maximum mortality $(22.58 \%)$ at $15 \%$ was recorded. The mean mortality was $6.36 \%$ at $5 \%$ concentration and $14.18 \%$ mortality was observed at $10 \%$ concentration of the plant extracts. From this it is concluded that mortality only increased with increase in concentrations of the 3 different plant oil and also shows that concentration has significant effect on percent mean percent mortality of $T$. granarium.

31. Comparison of the mean percentage mortality of Trogoderma granarium after exposure to different plant extracts after 48 hrs

\begin{tabular}{|c|r|}
\hline Concentrations (\%) & Mean percentage mortality \pm SE \\
\hline P1 & $7.23 \pm 1.21 \mathrm{c}$ \\
\hline P2 & $11.12 \pm 1.82 \mathrm{~b}$ \\
\hline P3 & $24.80 \pm 4.48 \mathrm{a}$ \\
\hline
\end{tabular}

Table 4.31 for percent mean mortality values of different plant extracts at different concentration levels showed that extracts of $R$. communis and Jatropha curcus gave mortality values 24.80 and $11.12 \%$,correspondly. While least mortality $7.23 \%$ was given by extract of Citrus paradise.

32. Comparative mean percentage mortality of Trogoderma granarium after exposure to different concentrations of plant extracts after 24 hrs

\begin{tabular}{|c|c|}
\hline Plant extracts $x$ Concentrations $(\%)$ & (\%) Mean Mortality \pm SE \\
\hline Citrus paradise $\times 5$ & $3.34 \pm 1.67 \mathrm{~g}$ \\
\hline Citrus paradise $\mathrm{x} 10$ & $8.34 \pm 1.67 \mathrm{efg}$ \\
\hline Citrus paradise $\mathrm{x} 15$ & $10.00 \pm 0.00 \mathrm{def}$ \\
\hline Jatropha curcus x 5 & $5.00 \pm 0.00 \mathrm{fg}$ \\
\hline Jatropha curcus $\mathrm{x} 10$ & $11.67 \pm 1.67 \mathrm{~cd}$ \\
\hline Jatropha curcus $\times 15$ & $16.67 \pm 1.67 \mathrm{bc}$ \\
\hline Ricinus communis $\mathrm{x} 5$ & $10.77 \pm 1.68 \mathrm{de}$ \\
\hline Ricinus communis $\mathrm{x} 10$ & $22.55 \pm 1.68 \mathrm{~b}$ \\
\hline Ricinus communis $\mathrm{x} 15$ & $41.07 \pm 1.68 \mathrm{a}$ \\
\hline
\end{tabular}


Table 32. showed the interaction between different concentrations (5, 10 and 15\%) and different exposure time period. Mean mortality of $T$. granarium was given in percentage by the application of extract of Ricinus communis, Jatropha curcus, Citrus paradise oil along with standard error in table 32.

Mean comparison of percentage mortality values of $T$. granarium at different concentrations of selected plant extract were highest at maximum concentration. Extract of Ricinus communis gave the highest mean mortality revealed that maximum mortality (41.07\%) at $15 \%$ was recorded. The mean mortality was $22.55 \%$ at $10 \%$ concentration and $10.77 \%$ mortality was observed at $5 \%$ concentration of the plant extracts. Extract of Jatropha curcus gave the mean mortality revealed that maximum mortality (16.67\%) at $15 \%$ was recorded. The mean mortality was $11.67 \%$ at $10 \%$ concentration and $5.00 \%$ mortality was observed at $5 \%$ concentration of the plant extracts. Extract of Citrus paradise gave the mean mortality revealed that maximum mortality (10.00\%) at $15 \%$ was recorded. The mean mortality was $8.34 \%$ at $10 \%$ concentration and $3.34 \%$ mortality was observed at $5 \%$ concentration of the plant extracts. The given outcome showed that interaction of exposure time and concentration was significant. From results we concluded that there was a gradually increase in mortality values with increase in concentration of plant extracts.

\section{MORTALITY DATA AFTER EXPOSURE OF 72 HRS}

Table 33. Analysis of variance (ANOVA) of the data concerning \% mortality of Trogoderma granarium (Herbst) for ZnO based nanoparticles

\begin{tabular}{|c|c|c|c|c|}
\hline S.O.V & DF & SS & MSS & F value \\
\hline Plant & 2 & 1774.278 & 887.139 & $95.0392 * *$ \\
\hline Concentration & 2 & 1746.274 & 873.137 & $93.5391 * *$ \\
\hline Plant*Concentration & 4 & 774.255 & 193.564 & $20.7365 * *$ \\
\hline Error & 18 & 168.020 & 9.334 & \\
\hline Total & 26 & & & \\
\hline
\end{tabular}

Table 34. Comparison of the mean percentage mortality of Trogoderma granarium after exposure to different concentrations of plant extracts after $72 \mathrm{hrs}$

\begin{tabular}{|c|r|}
\hline Concentrations (\%) & Mean percentage mortality \pm SE \\
\hline $\mathbf{5}$ & $8.59 \pm 1.27 \mathrm{c}$ \\
\hline $\mathbf{1 0}$ & $18.01 \pm 2.67 \mathrm{~b}$ \\
\hline 15 & $28.16 \pm 3.23 \mathrm{a}$ \\
\hline
\end{tabular}

Data in table 34. represents the insecticidal effect of different concentrations of 3 different oil against Trogoderma granarium. The experimental data revealed that maximum mortality $(28.16 \%)$ at $15 \%$ was recorded. The mean mortality was $8.59 \%$ at $5 \%$ concentration and $18.01 \%$ mortality was observed at $10 \%$ concentration of the plant extracts. From this it is concluded that mortality only increased with increase in concentrations of the 3 different plant oil and also shows that concentration has significant effect on percent mean percent mortality of $T$. granarium.

35 Comparison of the mean percentage mortality of Trogoderma granarium after exposure to different plant extracts after 72 hrs 


\begin{tabular}{|c|c|}
\hline Concentrations (\%) & Mean percentage mortality \pm SE \\
\hline P1 & $9.45 \pm 1.54 \mathrm{c}$ \\
\hline P2 & $15.06 \pm 2.04 \mathrm{~b}$ \\
\hline $\mathbf{P 3}$ & $27.73 \pm 3.58 \mathrm{a}$ \\
\hline
\end{tabular}

Table 4.35 for percent mean mortality values of different plant extracts at different concentration levels showed that extracts of $R$. communis and Jatropha curcus gave mortality values 27.73 and $15.06 \%$,correspondly. While least mortality $9.45 \%$ was given by extract of Citrus paradise.

36. Comparative mean percentage mortality of Trogoderma granarium after exposure to different concentrations of plant extracts after $72 \mathrm{hrs}$.

\begin{tabular}{|c|c|}
\hline Plant extracts x Concentrations (\%) & (\%) Mean Mortality \pm SE \\
\hline Citrus paradise $\times$ 5 & $5.00 \pm 0.34 \mathrm{~g}$ \\
\hline Citrus paradise $\times 10$ & $8.30 \pm 1.65 \mathrm{efg}$ \\
\hline Citrus paradise $\times 15$ & $15.01 \pm 0.85 \mathrm{def}$ \\
\hline Jatropha curcus $\times$ 5 & $9.47 \pm 1.81 \mathrm{fg}$ \\
\hline Jatropha curcus $\times 10$ & $16.64 \pm 3.31 \mathrm{~cd}$ \\
\hline Jatropha curcus $\times 15$ & $20.05 \pm 2.98 \mathrm{bc}$ \\
\hline Ricinus communis $\times 5$ & $12.45 \pm 1.68 \mathrm{de}$ \\
\hline Ricinus communis $\times 10$ & $25.15 \pm 2.91 \mathrm{~b}$ \\
\hline Ricinus communis $\times 15$ & $49.51 \pm 3.16 \mathrm{a}$ \\
\hline
\end{tabular}

Table 36 showed the interaction between different concentrations $(5,10$ and 15\%) and different exposure time period. Mean mortality of $T$. granarium was given in percentage by the application of extract of Ricinus communis, Jatropha curcus, Citrus paradise oil along with standard error .

Mean comparison of percentage mortality values of $T$. granarium at different concentrations of selected plant extract were highest at maximum concentration. Extract of Ricinus communis gave the highest mean mortality revealed that maximum mortality (49.51\%) at $15 \%$ was recorded. The mean mortality was $25.15 \%$ at $10 \%$ concentration and $12.45 \%$ mortality was observed at $5 \%$ concentration of the plant extracts. Extract of Jatropha curcus gave the mean mortality revealed that maximum mortality $(20.05 \%)$ at $15 \%$ was recorded. The mean mortality was $16.64 \%$ at $10 \%$ concentration and $9.47 \%$ mortality was observed at $5 \%$ concentration of the plant extracts. Extract of Citrus paradise gave the mean mortality revealed that maximum mortality (15.01\%) at $15 \%$ was recorded. The mean mortality was $8.30 \%$ at $10 \%$ concentration and $5.00 \%$ mortality was observed at $5 \%$ concentration of the plant extracts.The given outcome showed that interaction of exposure time and concentration was significant. From results we concluded that there was a gradually increase in mortality values with increase in concentration of plant extracts.

\section{ZINC OXIDE Nano-composites}


Electromagnetic radiation such as visible light is commonly treated as a wave phenomenon, characterized by a wavelength or frequencyVisible wavelengths cover a range from approximately 200 to $800 \mathrm{~nm}$. Optical properties of the as-prepared ZnO nanostructure sample was revealed by UV-Vis spectrum at room temperature, as shown in Figure No. 2.This graph was shown that the intense peak would be in $365 \mathrm{~nm}$ at room temperature in dried nanopowder form.

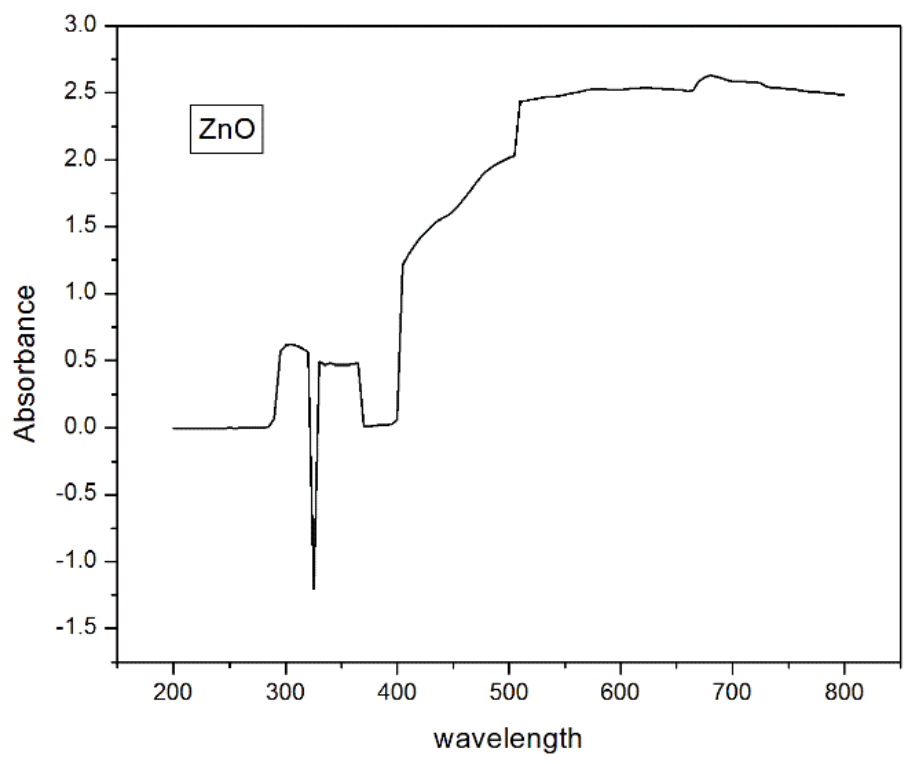

Figure 2: UV-Visible spectral analysis of $\mathrm{ZnO}$

\section{FTIR Spectra analysis of $\mathrm{ZnO}$}

Two milligram of Zno nanoparticales were prepared by FTIR spectra were recorded using a Nicolet 520P spectrometer with detector at 4000-400 cm-1 resolution and 20 scans per sample. FTIR Spectra of aqueous Zinc oxide nanoparticles prepared from the e Ricinus communis extract was carried out to identify the possible biomolecule responsible for capping and efficient stabilization of the metal nanoparticles synthesized by leaf broth. And their peaks was $3411.30 \mathrm{O}-\mathrm{H}$ Stretching, $2469.38 \mathrm{P}-\mathrm{H} \mathrm{Phosphine}, 2174.39 \mathrm{C}=\mathrm{C}=\mathrm{O}$ Stretching, 1557.44 C=O Vibration, 1409.53 CH2 Bending, 1117.32 O-C Stretching, 1085.04 O-C Stretching, 1020.47 P-OR Esters, 865.44 = CH2 Stretching, 842.14 P-O Stretching, 654.00 C-H Bending, 548.98 Zn-OH Rocking 


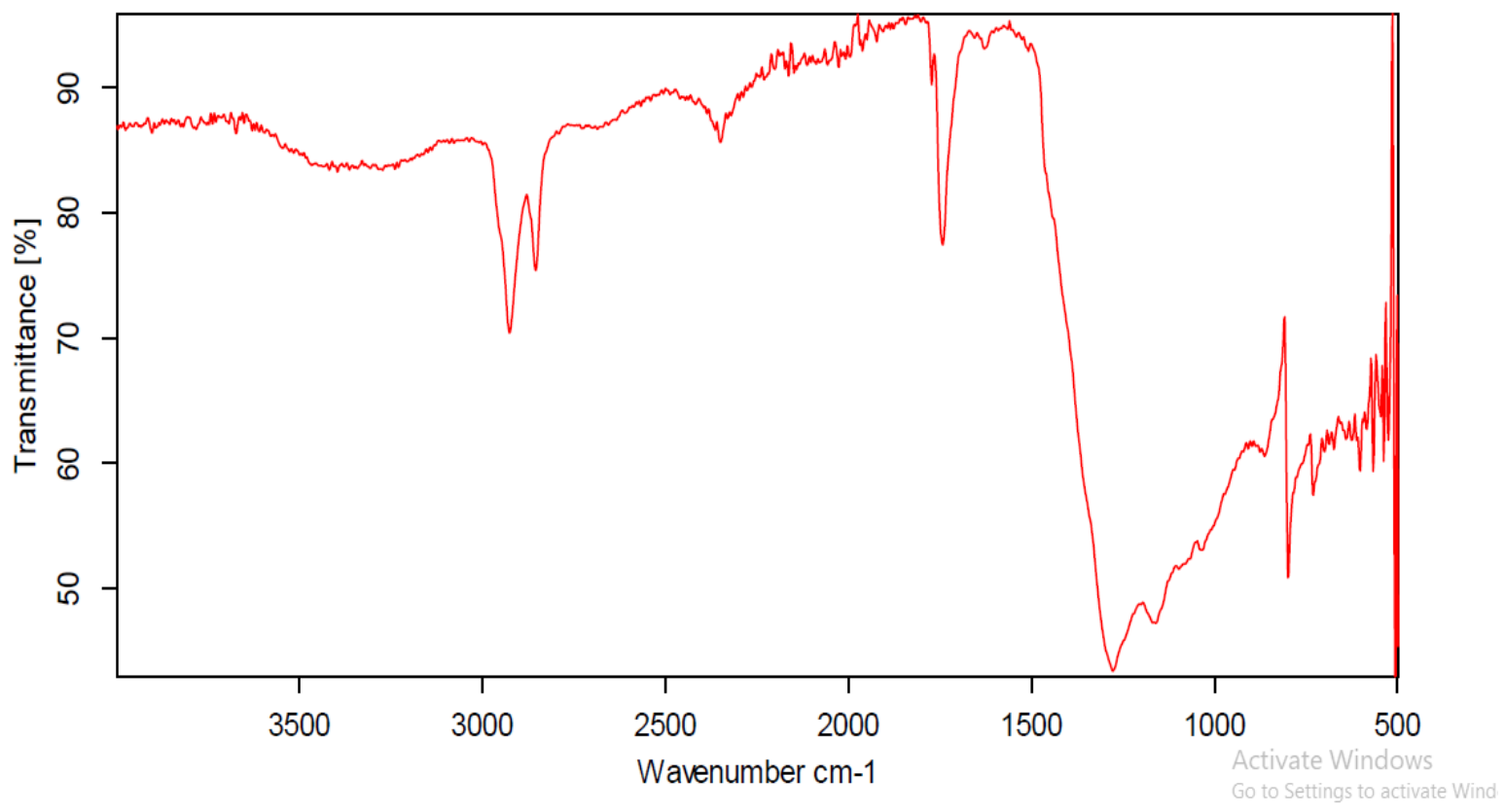

Figure.3

\section{CONCLUSION}

The present data gives the evidence that the modern Nanotechnology would also be prepare through the green synthesis method. Different solvents of plants extracts were used to prepare these nanoparticles. Tribolium castanium and Trigoderma granarium pests were created the huge effect on the soil fertility or growth. Different oil of plant extratcs were used to control this effects in past years, but it will not work properly. Hence now we can use the nano particles to control the huge disorder of fertility in our contory. Our experimnts shows that the nanoparticles works so well and so fast then the oil extracts. Results that given in the article can proved that thing properly.Therefore we can say that the nanoparticles recommended to farm leveal as for its cheap quality, availability, ecofriendly nature and good alternative form against the pest control.

\section{REFERENCES}

1. $\quad$ Sommer, S.G., et al., Techniques for measuring gas emissions from a composting stockpile of cattle manure. Atmospheric Environment, 2004. 38(28): p. 4643-4652.

2. Q Qazi, J., et al., Contribution of the satellite encoded gene $\beta C 1$ to cotton leaf curl disease symptoms. Virus Research, 2007. 128(1-2): p. 135-139.

3. $\quad \mathrm{Xu}, \mathrm{S}$., et al., Stretchable batteries with self-similar serpentine interconnects and integrated wireless recharging systems. Nature communications, 2013. 4(1): p. 1-8.

4. $\quad$ Rajput, V.D., et al., Effects of zinc-oxide nanoparticles on soil, plants, animals and soil organisms: a review. Environmental Nanotechnology, Monitoring \& Management, 2018. 9: p. 76-84.

5. $\quad$ Ahmadani, M.Y., et al., Clinical profile of fasting diabetic subjects during Ramadan. J Coll Physicians Surg Pak, 2007. 17(7): p. 446-7.

6. Andavan, G.S.B. and R. Lemmens-Gruber, Cyclodepsipeptides from marine sponges: Natural agents for drug research. Marine drugs, 2010. 8(3): p. 810-834.

7. Weaver, D.K. and B. Subramanyam, Botanicals, in Alternatives to pesticides in stored-product IPM. 2000, Springer. p. 303320 .

8. Mogg, K., et al., Subliminal processing of emotional information in anxiety and depression. Journal of abnormal psychology, 1993. 102(2): p. 304.

9. Goodwin, P.J., et al., Insulin-and obesity-related variables in early-stage breast cancer: correlations and time course of prognostic associations. Journal of clinical oncology, 2012. 30(2): p. 164-171.

10. Savitz, S.I., A critical appraisal of the NXY-059 neuroprotection studies for acute stroke: a need for more rigorous testing of neuroprotective agents in animal models of stroke. Experimental neurology, 2007. 205(1): p. 20-25. 
11. Lu, Z. and D.G. Streets, Sulfur dioxide and primary carbonaceous aerosol emissions in China and India, 1996-2010. Atmospheric Chemistry \& Physics Discussions, 2011. 11(7).

12. Enshassi, A., F. Arain, and S. Al-Raee, Causes of variation orders in construction projects in the Gaza Strip. Journal of Civil Engineering and Management, 2010. 16(4): p. 540-551.

13. Jood, S. and A. Kapoor, Protein and uric acid contents of cereal grains as affected by insect infestation. Food Chemistry, 1993. 46(2): p. 143-146.

14. Fields, P.G. and N.D. White, Alternatives to methyl bromide treatments for stored-product and quarantine insects. Annual review of entomology, 2002. 47(1): p. 331-359.

15. Zettler, J.L. and F.H. Arthur, Chemical control of stored product insects with fumigants and residual treatments. Crop Protection, 2000. 19(8-10): p. 577-582.

16. Brändle, A. and A. Khan, Thiol-epoxy 'click'polymerization: efficient construction of reactive and functional polymers. Polymer Chemistry, 2012. 3(12): p. 3224-3227.

17. Desneux, N., A. Decourtye, and J.-M. Delpuech, The sublethal effects of pesticides on beneficial arthropods. Annu. Rev. Entomol., 2007. 52: p. 81-106.

18. Sreenivas, D., et al., Genetic analysis of egg quality traits in White Leghorn chicken. Veterinary world, 2013. 6(5): p. 263.

19. Charles, D.J. and J.E. Simon, Comparison of extraction methods for the rapid determination of essential oil content and composition of basil. Journal of the American Society for Horticultural Science, 1990. 115(3): p. 458-462.

20. D'Anvers, J.-P., et al. Saber: Module-LWR based key exchange, CPA-secure encryption and CCA-secure KEM. in International Conference on Cryptology in Africa. 2018. Springer.

21. Sagheer, M.A., M.F. Khan, and S. Sharif, Association between chronic low back pain, anxiety and depression in patients at a tertiary care centre. J Pak Med Assoc, 2013. 63(6): p. 688-90.

22. Khalife, E., et al., Impacts of additives on performance and emission characteristics of diesel engines during steady state operation. Progress in Energy and Combustion Science, 2017. 59: p. 32-78.

23. Dobre, P. and S.. Jurcoane, Camelina crop-opportunities for a sustainable agriculture. Scientific Papers-Series A, Agronomy, 2011. 54: p. 420-424.

24. Kasthuri, J., S. Veerapandian, and N. Rajendiran, Biological synthesis of silver and gold nanoparticles using apiin as reducing agent. Colloids and Surfaces B: Biointerfaces, 2009. 68(1): p. 55-60.

25. Jamdagni, P., P. Khatri, and J. Rana, Green synthesis of zinc oxide nanoparticles using flower extract of Nyctanthes arbortristis and their antifungal activity. Journal of King Saud University-Science, 2018. 30(2): p. 168-175.

26. Suresh, C., et al., Facile LaOF: Sm3 + based labeling agent and their applications in residue chemistry of latent fingerprint and cheiloscopy under UV-visible light. Arabian journal of chemistry, 2018. 11(4): p. 460-482. 